\title{
Benefits of Career Guidance for Secondary Vocational School Students - Evaluation of a Pilot Program
}

\author{
(D) Jiř́ Votava ${ }^{1}$ Mgr., Ph.D.; (I) Jitka Jirsáková ${ }^{2}$ PhDr., Ph.D \\ Czech University of Life Sciences Prague, Institute of Education and Communication, Czech Republic \\ votava@ivp.czu.cz ${ }^{1}$;irsakova@ivp.czu.cz ${ }^{2}$
}

\begin{abstract}
Although career guidance in the Czech Republic is officially perceived as a priority of the education system, guidance support is not provided equally at all types of schools and on all levels of the education system. For example, we register insufficient support for students at secondary vocational schools. As previous research by the authors of the article has shown, it seems that once a young person decides to pursue a career, the effort of the school system to pay further attention to career guidance will also decrease. This paper is aimed to suggest a new program for career education, counselling and training, afterwards to pilot it at three secondary vocational schools, and with the help of action research to collect and to evaluate experience from the school practice. The empirical part of this article consists of three research phases. First, a baseline analysis was performed using mixed data resources (questionnaire survey among students, interviews with school counsellors and document analysis). In the second phase, a new career guidance program was proposed. Finally, the program was tested at three vocational schools in the years 2019 and 2020. Using action research design, the researchers gathered evidence and identified the benefits of new counselling activities. Based on these results, proposals for further improvement and implementation of career guidance and education at secondary vocational schools were submitted.
\end{abstract}

Keywords: career guidance, vocational education, training program, action research.

\section{Introduction}

There are many ways for scientific description of career decision-making processes and the progress of young people on their way of choosing their future profession. Because career development is a complex phenomenon (Patton, McMahon, 2014) that involves "the total constellation of psychological, sociological, educational, physical, economic, and chance factors that combine to influence the nature and significance of work in the total life span of any given individual" (Engles, 1994, 2), also the relevant career guidance practice should integrate as widely as possible all interpersonal and intrapersonal factors involved and the links with the different levels of the environment (micro-, meso- and macro-level). An example of a comprehensive approach is offered, among others, by the social cognitive theory of career development, which is based on the concept of self-efficacy (Bandura, 1986). It describes career development using five interconnected models: interest development, choice-making, performance and persistence in educational and vocational domains, a model of satisfaction and well-being in educational and vocational contexts, and a model of career self-management (Lent, Brown, 2013; Lent, Brown, 2019). Similarly, a holistic approach prevails in other contemporary concepts of career education. M. Savickas, for example, divides counselling activities into knowledge about oneself, knowledge about the profession, decision-making, planning and problem solving (Savickas et al., 2009). The holistic approach is also evident in his concept of career construction. If we apply these theories with such complexity to the practice of career counselling, it is clear that counselling should not only take just a few areas into account (development of interests and goal setting, for example) but it should seek to develop skills important for students' understanding of self-concept and career planning. However, the question is how the counselling system can cope with this task, or how an ideally compiled, comprehensively and integratively designed program might look like.

In this study the authors focus especially on the situation at upper vocational schools. From existing experience with career guidance and education it is clear that the support offered to students is not so complex and effective as would be expected. The dominant approach is still based on informing, instruction is organized in large groups with transmissive kinds of communication without more personal involvement of students (Jirsáková, Herout, 2017). Newer research pointed out that - with regard to future success of students - there are many methods that can aim effectively to develop the whole student personality and their career management skills (Soika, 2017; Rutina, Soika, 2020; Hirschi, Zacher, Shockley, 2020). Training tools are often based on the holistic view of trainee personality and its social development. For 
example, some authors recommended dialogical methodology (Soika, 2017) or strategies connected with experiential learning and on-the-job training (Guzman, Choi, 2013; Stan, 2016). Interpretation of recent research results from the Czech Republic (Jirsáková, Herout, 2017; Jirsáková, Votava, Urban, 2020) as well as from other European countries (Draaisma, Meijers, Kuijpers, 2018; Meijers et al., 2017) worried that the school system usually considers student decision processes as already completed on the upper secondary level. Therefore, most guidance activities are reduced to recommendations how to find a job or what to do in case of unemployment. There is very low motivation of counselling practitioners to support career exploration and career planning in the broader sense (David et al., 2020). The aim of this paper is, on the grounds of previous investigations, to suggest a new program for career education, afterwards to pilot it at three secondary vocational schools, and with the help of action research to collect and to evaluate experience from the school practice. After consideration of evaluation results the tested program will be improved and disseminated to other secondary vocational schools, teachers and counsellors. The overall intention could be summarized in two main research questions: What is the starting point in the field of career guidance and career education at three selected vocational schools? What experience did the pilot testing of a new career guidance program bring and what recommendations did arise out of this trial?

\section{Methodology}

To achieve the goals, the methodology of action research was chosen. This approach is recommended, for example, in the case of verification of a new educational method or program in the real environment (Cohen, Manion, Morrison, 2018). According to J. McNiff and J. Whitehead, action research should be divided into four following steps: evaluating existing practices identifying what needs to be improved, designing innovative practices, and testing them with subsequent evaluation. Another important feature of this strategy is the continuation of the investigation with additional adjustments and recurring evaluation: research in action (McNiff, Whitehead, 2010, 58). Another reason for choosing action research methodology was the possibility to combine different sources of input data (quantitative, qualitative) and to treat the personal experiences of researchers who participate in the experimental program as trainers (Kemmis, McTaggart, 2003). Action research also makes it possible to work with living, evolving and as yet unfinished pedagogical reality (Ivankova, Wingo, 2018). Repetitive feedback between actions helps to develop and to test the new end product.

In total, the research was divided into three parts. First, the initial state of career counselling in three selected secondary vocational schools was described (baseline analysis). These institutions belong among application partners of the project and have agreed in advance with the pilot testing of the newly developed methodology. The description of the initial situation in the three secondary schools included results of a questionnaire survey among final year students, information obtained from career counsellors through interviews, an analysis of school documents, and a description of the structure of the offer of educational programs. The state of career counselling was assessed at the level of an individual institution and based also on a comparison of three institutions with a larger sample of secondary vocational schools (benchmarking). Second, on the ground of the baseline assessment, a pilot career guidance program was designed and prepared for the check. In the third phase of the action research, the realisation process and results of the pilot program were evaluated to estimate the effects of performed guidance activities and to propose the necessary modifications of the new methodology for its future application. The evaluation of individual activities was carried out based on a reflective diary of lecturers and on the feedback gathered from students through reflective written and oral communication after each activity or at the end of the whole piloted module. The feedback was also provided by teachers (career counsellors).

\section{Results and Discussions}

\section{Baseline - description}

Three upper secondary vocational schools took part in the action research. These institutions are further in the text labelled with the letters A, B, C. All three schools are public institutions, established by a regional government ("kraj"), and all three offer education at ISCED level 3. The school attendance is completed by a school-leaving examination or an apprenticeship certificate. The school focuses on the automotive industry and information technologies (IT). In 2019, it was attended by 736 students. The team of the school counselling centre consists of four internal employees who, in addition to career 
counselling, focus, for example, on the prevention of risk behaviour or the support of individuals with special educational needs. The school cooperates with an external psychologist. A career counsellor has been working in education for 16 years, of which he has been involved in career counselling for 10 years. $\mathrm{He}$ is not qualified for career counselling, but he has a pedagogical education. In addition to career counselling, he teaches economics. During the school year, he spends an average of 3 hours a week on career guidance. He uses practically all methods of career counselling. He cites coaching interviews as proven, while he considers giving advice ineffective. The counsellor organizes extensive cooperation with employers, organizes a career day at school, and includes topics related to career counselling in his teaching. School B specializes in teaching art disciplines. In 2019, it was attended by 439 students. There are two employees in the school counselling centre, one specializing in career counselling, in which he spends an average of 2 hours per week. This person has been working in education for 25 years, of which 13 in career counselling. The counsellor has obtained qualification for career guidance through specialized study. In addition to counselling, he teaches mathematics, information and communication technologies and vocational subjects. In 2019, School C was attended by 395 students studying gastronomic disciplines and other specializations. School counselling is provided by three employees, one focusing on career guidance. He has the qualification of a school psychologist. He has been working at the school for one year. Apart from counselling, he does not teach any other subjects. According to his estimate, he devotes 21 hours a week to school counselling, of which one hour is spent on career guidance.

The research team was interested in the extent to which career guidance and education are provided in three schools. One of the first sources of information was the results of a questionnaire survey, in which a total of 43 schools in the Czech Republic participated. The data relevant for the whole sample are displayed in the column titled "All schools". Respondents mostly attended the last years of upper vocational schools. It was therefore possible to assume that they should have already engaged in career counselling and education. To assess the baseline, relevant results from three pilot schools were selected and compared with the whole sample. Table 1 shows that there is insufficient overall awareness of career guidance opportunities. Only about a fifth of respondents (even only $4 \%$ in one of the pilot schools) know who is responsible for career guidance. The similar result is about knowledge of the concept of career counselling.

Table 1

Awareness of career guidance (\%)

\begin{tabular}{|l|c|c|c|c|}
\hline & A & B & C & All schools \\
\hline Do you know, who in your school is in charge of career guidance? & 15 & 26 & 4 & 22 \\
\hline Have you ever heard the term career guidance in your school? & 22 & 19 & 7 & 18 \\
\hline
\end{tabular}

The questionnaire also mapped students' experiences of various forms of activity, which are usually part of career guidance (Table 2, for description of the Czech system of career guidance and education, see also Jirsáková, Votava, Urban (2020)).

Table 2

Students' experience with career guidance activities (in \%)

\begin{tabular}{|l|c|c|c|c|}
\hline & A & B & C & All schools \\
\hline Presentation of companies / employers at your school & 74 & 35 & 72 & 63 \\
\hline Practical training outside of schools (on-the-job training) & 55 & 26 & 51 & 50 \\
\hline Excursions to companies & 43 & 26 & 13 & 39 \\
\hline Participation in job fairs and exhibitions & 36 & 26 & 12 & 36 \\
\hline $\begin{array}{l}\text { Programs at your school realized, for example, by a labour office or a } \\
\text { pedagogical-psychological counselling centre }\end{array}$ & 19 & 21 & 5 & 33 \\
\hline Psychological testing & 17 & 21 & 5 & 32 \\
\hline Group activities in instruction, focused on choosing a profession & 16 & 16 & 3 & 25 \\
\hline $\begin{array}{l}\text { Programs organized outside your school (in a labour office, counselling } \\
\text { centre or other institutions) }\end{array}$ & 9 & 9 & 3 & 25 \\
\hline An individual interview / consultation with you and a counsellor & 7 & 7 & 3 & 15 \\
\hline
\end{tabular}


Students have most often experience with presentations of employers, they take part in excursions to various companies, and get ideas about their future profession during internships at contracted workplaces. There are obvious differences in the students' experiences: in schools A and C contacts with employers were more frequent than in school B. The reason may be that school B offers mainly artistic disciplines, in which training occurs mainly in school workshops and not outside. In schools A and B, less than a fifth of respondents encountered psychological tests or group forms of guidance, in school $\mathrm{C}$ it is even less so, which may indicate a different approach and strategy of services offered, but also less overall support for career counselling by the school management. Surprising is the very low incidence of individual forms of guidance and counselling, such as a counselling interview - in schools A and C around $7 \%$, in school B only about $2 \%$ of students gained such experience. These numbers may indicate that there is insufficient staff capacity in career guidance, or that school counsellors prefer more frontal work with the whole class or they just distribute information.

As the next part of baseline analyses results from a diagnostic battery of twenty-one questionnaire items were processed. These items investigated which areas of career guidance and education the students from three pilot schools already encountered during their school attendance and in which areas they need to develop further. The diagnostic battery contains three basic categories of topics: further education, labour market and soft skills.

According to the students' answers, all items were lined up in two rows. The first sequence corresponded with the occurrence of each topic in the school education (for example, practically all students have already created a PowerPoint presentation). The other one was lined up according to the interests of students to learn more in these areas. By comparing the two rows, we determined the following four types of topics from the perspective of students:

- frequently taught topics, high motivation of students (for example, how to start a business, recognition of own strengths and weaknesses, preparing for a job interview, presentation in public (e.g., how to speak in front of others));

- poorly taught topics, high motivation of students (opportunities to study abroad, opportunities to work abroad, stress management; how to learn effectively);

- frequently taught topics, low motivation of students (what to do in case of unemployment, searching for job offers via the Internet, how to find a job in the profession which I study, what to do if I do not like my current direction, requirements of employers in the field what I study, my rights and responsibilities as an employee, what can I do to overcome learning difficulties, writing a $\mathrm{CV}$, preparation of a presentation);

- poorly taught topics, low motivation of students (how to determine which field of further education would be suitable for a student, how to plan further education (where and how to continue with education) and what ideas do students have about their future life.

It follows that students in all three schools prefer to develop certain areas of soft skills (such as job preparation, stress management, or learning to learn effectively) because they assume that they will need them when applying for a job. They lack support for foreign mobility in the field of further study or employment. The fourth group of topics is interesting. It seems that neither the school nor the students need to learn more about their future careers, about their further education, or about life plans and the future in general. However, this does not mean that this area of counselling does not make sense, but, likely, counsellors, teachers, and students did not have the opportunity to try it out and assess its possible benefits. The results also show differences between schools. School A, which focuses on the automotive field, highlights the students' need to learn how to start a business but does not feel the need to help them find a future job, as there are plenty of job offers in this sector. We could also assume that students from A are more pragmatic and confident.

Overall, awareness of career guidance at the three pilot schools is low. Students most often have experience with presentations of companies that cooperate with schools or attend trade fairs for job opportunities and educational offers. Schools lack methods focused on decision-making processes and career planning (individual and group activities, self-knowledge activities). Students themselves often take a pragmatic approach; they would like to focus on some areas of soft-skills in their learning. On the contrary, they are not interested in topics related to career planning and ideas about future life, which, 
however, does not exclude that these topics may also be important. It is also clear that there is not enough time allocated for career guidance.

\section{Project of a new Career Guidance Program}

The pilot study at three secondary vocational schools was the first test to show the advantages and disadvantages of the counselling techniques and approaches used to guide students' further career adaptation and development. The experience from the pilot verification will help to fulfil the intention of the whole project, thus to prepare a range of counselling activities for secondary vocational schools in the future, which should correspond to knowledge and theories about career development, secondary vocational school environment, and career maturity of pupils at different stages of training.

The pilot validation had to respect school regulations and work capacity of the research team. To test in the given time as many activities as possible, the pilot of the new program was divided between schools $\mathrm{A}, \mathrm{B}$, and $\mathrm{C}$ and among pupils of different grades. The pilot program was focused mainly on students with specialization in IT, multimedia communication, artistic processing of wood and metals, and breeding of exotic animals. Types of study direction were intentionally different. Three lecturers in cooperation with the school career counsellor, who always participated in the program and had access to all materials, oversaw the preparation and implementation of the counselling activities.

Thematically, the pilot verification was divided into three parts - self-knowledge and knowledge of others (identification and naming of their own abilities and skills, self-presentation and personal branding), employers' expectations and labour market requirements (how and where to look for work), "elevator pitch" training and job interview. The topics of self-knowledge were used mainly by second-year students. Third- and fourth-year students paid more attention to preparation for the labour market, their own self-presentation, and methods of finding a job. For example, the following methods were used in the pilot program: working with mentoring cards, photographs, video, working with a story, role-playing, worksheets. Thanks to the activities, students should be able to identify their abilities, learn how to prove their competencies, think about work values, consider what they expect from work, and how work should fulfil them. Pupils eventually tried to connect their competencies with job positions. They deepened their self-knowledge with the help of a personality questionnaire.

\section{Results of the program evaluation}

In school A, five modules were implemented with the extent of three to four teaching hours among students of the second year with a specialization in multimedia. A total of 18 teaching hours were held in this class from October to December 2019. These were mostly activities for self-knowledge, revealing and naming strengths, self-promotion, completing the personality typology test, and individual analysis of test results. All activities were subsequently discussed with the pupils during follow-up lessons with a career counsellor. In the third and fourth year of the study direction IT and multimedia communication classes were held in February, early March, and September 2020. There were between 15 and 22 persons in the class. In this case the program contained a reduced part of self-knowledge activities. More attention was paid to information about the labour market, to activities of HR specialists, and to procedures of employee selection, including training in a job interview and writing a CV. Students also had the opportunity to visit a company operating in information technologies and thus obtain knowledge about the use of information technology in the retail chain. They got acquainted with the course of recruitment to an international company, with the requirements for IT positions, and finally they could try out the assessment centre. Students saw the benefit of the piloted program mainly in getting to know their classmates in individual activities. They greatly appreciated the opportunity to participate in such activities and think about themselves and their future, although most do not yet have an exact idea of where they want to enter the labour market. They also acknowledged the personal analysis of the completed tests. In the reflection, for example, the students stated: "I am glad that we were able to have these activities, I enjoyed it and it gave me a lot of things for the future." "I learned something new and found that my direction was right." "I know more about myself and I know what to expect from work." "I learned a lot about my character." "I know what's right for me and I know which way to go." "I enjoyed mumbling about myself for one and a half minutes, I didn't expect it to be that hard."

Students from school B completed the same type of activities, but these were the third and fourth years of the artistic fields of carpenter, blacksmith, and woodcarver (autumn 2019 and winter 2020). There 
were always between 15-20 students in the class. Modules were taught during a project week focused on the employment of students, which included both our activities and visits to various employers at the school. The feedback from the participants showed that the activities of the first block focused on selfknowledge were unusual for them. They had to open up to themselves and to the group of their classmates, which caused problems for some of them. Gradually, they gained confidence, and activities earned meaning for them. It was obvious that this type of exercise was new to them. In the second block, which focused on finding a job and building a career, the students already cooperated, they were active, because they themselves were already looking for part-time jobs and opportunities for further study, and they were already partially oriented in this issue. The first block of activities brought them specific information about the labour market, introduced them to activities of HR specialists, and to procedures of employee selection. Students understood the complexity and interconnectedness of the world of work. In contrast to school A, these students in most cases have a clear idea of their employment. In this case, the intention was rather to show them in the individual activities why it makes sense to do the activity and what new they will learn from it. There was a greater focus on practical advice and tips for entering the labour market. They did not show as much interest in self-knowledge activities as students from schools A and C. "I'm thinking what I really want from my job." "I hate to talk about myself, but it gave me something." "I didn't know the career web pages of companies and how to read it." "Something could be shorter; I would add more advice for practice."

In school C, verification occurred in the autumn of 2019 in the extent of three meetings in the second year of the study program breeding exotic animals. During the pilot verification, it was known that there were 30 students in the class, which turned out to be more demanding for this type of teaching in terms of organization and implementation of activities. On the other hand, it was mostly a girls' class, so they may have become more actively involved, appreciating self-knowledge activities and learning about their classmates. Further pilot verification was stopped due to school closures caused by the Covid-19 pandemic. The only thing that could be maintained was online analyses of personality questionnaires, which we conducted both online and by phone.

All activities were always attended by the career counsellor of the school, who had the opportunity to observe tasks, assignments and reflective discussions. The project team also made all materials accessible for school counselling professionals. The efficiency and effectiveness of tested activities were discussed after each module so that it would be possible to adjust all activities in the next school year.

As an example of how the program was evaluated by the career counsellors themselves, we would like to mention the statement of one of them: "The students enjoyed the lessons a lot. They were especially happy about the opportunity to complete the personality questionnaire. If they just filled in this questionnaire, got the results and that ended it, it would not make much sense to them. If you really go through the questionnaire with them, then the benefit is considerable. What was fascinating for me was that I and other students in the class learned a lot of interesting things about schoolmates only in the 4 th grade. Therefore, it was also a great benefit for me as a teacher. I can clearly say that I wish there would be more projects of this type in schools and there would be more people working on similar projects with such enthusiasm."

\section{Conclusions}

The present epoch is favourable for the development of career guidance. It seems to be necessary to support young people in developing their career management skills. The "Corona crisis" has shown that it is essential to be prepared for changes in the labour market, to be able to respond to current social and economical conditions, and to be able to adopt both new and flexible scenarios in one's own career path. This opinion corresponds to the need to develop further career guidance activities not only in primary education but also in secondary schools. The substantial part of this task aims to activities that can go deeper in the trainee personality (avoiding just distribution of information) and can be more complex (covering all components and phases of career development).

Students at secondary vocational schools have, so to speak, chosen their direction, they are already preparing for their future profession. They take part in professional internships, participate in competitions, projects, and practical training in companies. However, do they really know what they want to do in the future? Where and how will they be able to apply what they learned in school? Are 
they ready for the reality of the labour market? The mission of secondary vocational schools should be to offer conscious preparation for the chosen profession. Schools should show the pros and cons of a future career, motivate students for the profession, and launch a new workforce prepared both professionally and socially. To reach this aim, schools should be helped by a functionally set career guidance strategy, which each school should tailor itself according to its own conditions. The school should answer the question of who its graduate is, which competencies should this graduate possess, how to use acquired competencies in practice and which competencies are required by the labour market.

Therefore, at the beginning of our project, we conducted both a quantitative survey among students and teachers and subsequently a qualitative survey (interviews) with career counsellors at our three pilot schools. It was found that awareness of career counselling is very low among students, a small percentage had the opportunity to try individual counselling. It turned out that schools lack an overall strategy for the development of career counselling at school, although they have more or less support of school management, most counselling activities are based primarily on their time options and enthusiasm of each individual counsellor.

The pilot study clearly showed that students of various disciplines do not have much experience with career counselling. For this, they are willing to think about themselves and their future employment, they want to know themselves better and they are willing to try new activities that will help them see not only themselves but also their classmates in a new light. They also greatly appreciated the individual consultations and the analysis of the personality questionnaire. There was also a difference between schools and classes, especially in their gender composition and number. The ideal number of pupils is between 15 and 20 for the effective implementation of activities. If boys predominate in the class, the emphasis on the practicality and applicability of the acquired knowledge and skills has increased, including the justification of the benefits of the activity. The feedback from career counsellors and, in fact, the students, showed that they were happy with an external form of teaching, it was easier for the students to establish a relationship and to be more open than they would be in case the program was provided only by a schoolteacher. It has been verified for us as instructors that it is necessary to know the school environment, educational programs of individual fields and to establish cooperation with the school management and the career counsellor.

In the next year of piloting, due to the COVID-19 pandemic and the limited regime of secondary vocational schools, we are also preparing online variants of activities and online materials for career counsellors in schools so that they have all necessary information and materials together and available.

\section{Acknowledgement}

This article was supported by the Technology Agency of the Czech Republic, the ÉTA program under the grant: "Design and Implementation of the Concept and Methodology of Career Learning in Vocational Education" (TL02000256).

\section{Bibliography}

1. Bandura A. (1986). Social foundations of thought and action: A social cognitive theory. Englewood Cliffs, NJ: Prentice-Hall.

2. Cohen L., Manion L., Morrison, K. (2018). Research methods in education. London: Routledge.

3. David L.T., Cazan A.A., Albisser S., Keller-Schneider M. (2020). Exploring the impact of a career guidance intervention program in schools: Effects on knowledge and skills as self-assessed by students. Current Psychology, No. 180. doi: 10.1007/s12144-020-00973-0

4. Draaisma A., Meijers F., Kuijpers M. (2018). The development of strong career learning environments: the project 'Career Orientation and Guidance' in Dutch vocational education. Journal of Vocational Education \& Training, 70(1), 27-46. doi: 10.1080/13636820.2017.1392995

5. Engles D. (Ed.). (1994). Professional Practice of Career Counseling and Consultation ( $\left.2^{\text {nd }} \mathrm{ed}\right)$. Alexandria: National Career Development Association and American Association for Counseling and Development.

6. Guzman A.B., Choi K.O. (2013). The relations of employability skills to career adaptability among technical school students. Journal of Vocational Behavior, 82(3), 199-207, doi: 10.1016/j.jvb.2013.01.009 
7. Hirschi A., Zacher H., Shockley K.M. (2020). Whole-Life Career Self-Management: A Conceptual Framework. Journal of Career Development. Online first. doi: 10.1177\%2F0894845320957729

8. Ivankova N., Wingo N. (2018). Applying Mixed Methods in Action Research: Methodological Potentials and Advantages. American Behavioral Scientist, 62(7), 978-997. doi: $10.1177 \% 2 F 0002764218772673$

9. Jirsáková J., Herout L. (2017). Career guidance at vocational schools in Czech Republic. In L Gómez Chova, A. López Martínez, I. Candel Torres (Eds.), The Proceedings of the International Conference on Education and New Learning Technologies (EDULEARN), 9. Barcelona, Spain: IATED, 6014-6022. doi: 10.21125/edulearn.2017.2362

10. Jirsáková J., Votava J., Urban K. (2020). Experience and Awareness of upper Secondary School Students with Career Counselling in Czech Republic. In V. Dislere (Ed.), The Proceedings of the International Scientific Conference Rural Environment. Education. Personality (REEP), 13. Jelgava: Latvia University of Life Sciences and Technologies, 412-419. doi: 10.22616/reep.2020.048

11. Kemmis S., McTaggart R. (2003). Participatory Action Research. In N.K. Denzin, Y.S. Lincoln (Eds.), Strategies of qualitative inquiry. Thousand Oaks: SAGE Publications, 336-396.

12. Lent R.W., Brown S.D. (2013). Social cognitive model of career self-management: Toward a unifying view of adaptive career behavior across the life span. Journal of Counseling Psychology, 60(4), 557-568. doi: 10.1037/a0033446

13. Lent R.W., Brown S.D. (2019). Social cognitive career theory at 25: Empirical status of the interest, choice, and performance models. Journal of Vocational Behavior, 115, 103316. doi: 10.1016/j.jvb.2019.06.004

14. McNiff J., Whitehead J. (2010). You and Your Action Research Project (3 ${ }^{\text {rd }}$ ed.). London: Routledge, doi: 10.4324/9780203871553

15. Meijers F., Lengelle R., Winters A., Kuijpers M. (2017). A Dialogue Worth Having: Vocational Competence, Career Identity and a Learning Environment for Twenty-First Century Success at Work. In E. de Bruijn, S. Billett, J. Onstenk (Eds.), Enhancing Teaching and Learning in the Dutch Vocational Education System. Professional and Practice-based Learning, 18. Cham: Springer International Publishing, 139-155. doi: 10.1007/978-3-319-50734-7_7

16. Patton W., McMahon M. (2014). Career Development \& Systems Theory. Connecting Theory and Practice. Rotterdam: Sense Publisher. doi: 10.1007/978-94-6209-635-6

17. Rutina K., Soika I. (2020). Career Guidance for First-Year Students in Work-Based Learning. In V. Dislere (Ed.), The Proceedings of the International Scientific Conference Rural Environment, Education, Personality (REEP), 13. Jelgava: Latvia University of Life Sciences and Technologies, 441-449. doi: 10.22616/REEP.2020.052

18. Savickas M.L., Nota L., Rossierc J., Dauwalder J.P., Duarte M.E., Guichard J., Soresi S., Van Esbroeck R., Van Vianen A.E.M. (2009). Life designing: A paradigm for career construction in the 21st century. Journal of Vocational Behavior, 75(3), 239-250. doi: 10.1016/j.jvb.2009.04.004

19. Soika I. (2017). Evolution of Dialogue for Students' Career Guidance in Secondary Vocational Education. In V. Dislere (Ed.), The Proceedings of the International Scientific Conference Rural Environment. Education. Personality (REEP), 10. Jelgava: LLU, 481-488. Retrieved from https://lufb.llu.lv/conference/REEP/2017/Latvia-Univ-Agricult-REEP-2017_proceedings-481-488.pdf

20. Stan C. (2016). The Relationship between Career Counselling, Professional Practice and Desirable Labour Market Integration. In the Proceedings of the International Conference Education, Reflection, Development (ERD 2016), 4, 607-614. doi: 10.15405/epsbs.2016.12.75 